\title{
Estimation of Reference and Crop Evapo-Transpiration in Panam Canal Command using Remote Sensing and GIS
}

\author{
Sanjaykumar H. Parmar* and Mukesh K. Tiwari \\ Department of Irrigation and Drainage Engineering, College of Agricultural Engineering and \\ Technology, Anand Agricultural University, Godhra-389001, Gujarat, India \\ *Corresponding author
}

A B S T R A C T

\begin{tabular}{l} 
K e y w o r d s \\
Evapotranspiration, \\
Reference \\
evapotranspiration, \\
Actual \\
evapotranspiration, \\
Satellite MODIS \\
Image, Maize crop \\
water requirement \\
\hline Article Info \\
\hline $\begin{array}{l}\text { Accepted: } \\
\text { 20 July 2020 } \\
\text { Available Online: } \\
\text { 10 August } 2020\end{array}$ \\
\hline
\end{tabular}

Determination of reference evapotranspiration $\left(\mathrm{ET}_{0}\right)$ is a key factor for estimation of crop water requirement, water balance and irrigation scheduling. The FAO-56 Penman-Monteith equation has been accepted universally for estimating of reference evapotranspiration $\left(\mathrm{ET}_{0}\right)$. This method demands a number of climatic parameters that are not always available. The determination of water needed for irrigating crops is one of the main parameters for correct irrigation planning. In this context the FAO Penman - Monteith (FAO- PM) has been recommended as the best for the evapotranspiration $\left(\mathrm{ET}_{\mathrm{o}}\right)$ estimates. The traditional methods require several meteorological and crop data even for estimation of point $\mathrm{ET}_{0}$. Remote sensing images have recently been applied to estimate temporal and spatially distributed $\mathrm{ET}_{0}$ very effectively and timely. The determination of actual evapotranspiration of specific crops needs acquisition and routine processing of daily remote sensing images, which seems time consuming and expensive. In present study, daily, monthly, and yearly $\mathrm{ET}_{\mathrm{o}}$ were determined for 2 stations namely Godhra, and Veganpur located in Panam canal command, middle Gujarat region using long period (11 Year) weather data applying FAO-56 Penman-Monteith and Hargreaves equations. Further, in this study actual ET was estimated using MOD16 remote sensing data. The present study was also undertaken to estimate and compare the crop water requirement (ETc) of maize crops using field methods and remote sensing data based estimation in winter season of Panam command region, Gujarat. The growth stage wise crop coefficients (Kc) taken for daily climatic variation were used to estimate the daily ETc for the maize crops. It was found in this study that remote sensing based data has very similar performance for estimation of $\mathrm{ET}_{0}$ as compared to point estimation using field studies.

\section{Introduction}

Evapotranspiration plays an important role in areas of ecology, hydrology and atmospheric sciences. ET is the second most important element of the hydrological cycle after precipitation because it facilitates the continuation of precipitation by replacing the vapour lost through condensation (Brutsaert, et al., 2009). ET is also crucial for the transportation of minerals and nutrients required for plant growth; creates a beneficial cooling process to plant canopies in many climates; and influences the Earth's energy and water balance because of the direct association with latent heat flux (LE). ET consumes large amounts of energy during the conversion of liquid water to vapor, hence playing an important role in hydrology, agriculture, climatology and meteorology. 
Accurate estimates of ET contribute to improved quantification of the catchment water balance and in the facilitation of decision making for sustainable water resource management (Allen et al., 2007; Mu et al., 2007; Su et al., 2002).

The accuracy of ET derived from remote sensing data sources varies over space and time with an uncertainty of 15-30\% (Mu et al., 2007; Senay et al., 2008), which may go up to $50 \%$ of the total mean annual ET values for the large-scale estimates (Glenn et al., 2010). Hence, the evaluation of coarse resolution ET data has been an ongoing concern. Similarly, the validated MODISderived ET products reveal that the MOD16 algorithm performs the best at forest sites and poor at the sites in arid and polar climates (Kim et al., 2012); and also, it has the drawback of not exhibiting the variation for double-cropping system. However, these validation studies are either restricted by space or time, without considering the longer time periods, varied agro-ecosystems and larger areas. Furthermore, there are limited evaluations of the ET estimated from the MODIS normalized difference vegetation index (NDVI), MODIS enhanced vegetation index (EVI) and MODIS land surface temperature (LST) products in comparison with the 'traditional water balance' approach (Senay et al., 2011).

The MOD16 and Land Surface Analysis Satellite Application Facility Meteosat Second Generation (LSA-SAF MSG) ET products perform the best for the sites located in a temperate and fully humid climate, whereas they underestimate the ET for the sites located in a semi-arid climate ( $\mathrm{Hu}$ et al., 2015). MOD16 ET is overestimated for forested areas due to not taking account of the leaf shadowing effect and also underestimated in poorly vegetated areas (Jang et al., 2013; Rameolo et al., 2014). Further, MOD16 ET is highly underestimated when it is compared with the eddy covariance flux towers (Autovino et al., 2016).

Geographical information system (GIS) is a system for capturing, storing, checking, integrating, manipulating, analysing and displaying data which are spatially referenced to the Earth. This is normally considered to involve a spatially referenced computer database and appropriate applications software. GIS handles spatial information referenced by its location in space. GIS makes connections between activities based on spatial proximity special case of information system where the database consists of observation some spatially distributed features, activities or events, which are definable in space as points, lines or area. A geographic information system manipulates data about these points, lines and areas to retrieve data for adhoc queries and analyses.

Accurate estimation of crop water requirements $\left(\mathrm{ET}_{\mathrm{c}}\right)$ of any crop is essentially required for irrigation scheduling and water management. The present study was undertaken to estimate the crop water requirement $\left(\mathrm{ET}_{\mathrm{c}}\right)$ for Maize crop grown in winter seasons in Panam command area of middle Gujarat region. The daily reference evapotranspiration $\left(\mathrm{ET}_{\mathrm{o}}\right)$ was estimated by FAO Penman-Monteith method using 11 years (2006 to 2016) meteorological data of Panam command. The most common and practical approach widely used for estimating crop water requirement, and the operational monitoring of soil-plant water balance is the FAO-56 method. In the FAO-56 approach, crop evapotranspiration is estimated by the combination of a reference evapotranspiration $\left(\mathrm{ET}_{\mathrm{o}}\right)$ and crop coefficients.

In the present study, an attempt was made to estimate reference evapotranspiration, crop evapotranspiration and water requirement of 
maize crop in semiarid climatic condition with the objectives to estimate reference evapotranspiration using the FAO-56 Penman-Monteith equation, to estimate the actual evapotranspiration using satellite-based MODIS data, and to estimate actual evapotranspiration using crop coefficients and reference evapotranspiration for maize crop in the panam command area.

\section{Materials and Methods}

\section{Study area}

The study area of the Panam command which contains two climatic regions, the northern part of the command comprises subtropical wet climate. The major part of command comprises tropical wet climate, caused mainly due to existence of Vindhyas and the Western Ghats. The project area experiences minimum temperature of $14.8^{\circ} \mathrm{C}$ in January and maximum temperature $43.5^{\circ} \mathrm{C}$ in May. Average annual rainfall in the area is $940 \mathrm{~mm}$. About $80 \%$ of the rainfall occurs during the month of July and August. On an average there are only 35 to 40 rainy-days per annum, which mostly fall during the period mid June to mid-September. There are frequent dry spells occurring over years. The location map of the study area is presented in Fig. 1.

\section{Data collection}

The data of pan evaporation, air temperature, relative humidity, wind speed and sunshine hours, were collected from Panam Circle, Godhra and Weather Station, Veganpur. Meteorological data for a period of eleven years (2006 to 2016) were used in the study (Table 1).

\section{Major crops}

The major crops grown in the study area are Paddy, Castor, Jowar, Bajra, Maize and Wheat. Paddy is the major crop cultivated during Kharif season and Maize is the major crop grown in Rabi season.

\section{Methodology}

\section{Computation of evapotranspiration using satellite-based MODIS data}

MOD16 ET algorithm is based on the Penman-Monteith equation (Monteith, 1965) as presented in Eq1.The MODIS global ET algorithm is a part of NASA's Earth observing system for estimating ET from Earth's land surface using MODIS remote sensing data for hydrological and ecological applications. The MOD16 (Mu, et al., 2011) product is based on the beta version of the algorithm (Mu, et al., 2007) developed from Cleugh et al., (2007) using a-Monteith approach (Monteith, 1965).

$$
E T=\frac{\Delta\left(R_{n}-G\right)+\rho_{a} C_{p} \frac{\left(e_{s}-\rho_{a}\right)}{r_{a}}}{\Delta+\gamma\left(1+\frac{r_{s}}{r_{a}}\right)}
$$

Where,

$\mathrm{ET}=$ Daily evapotranspiration $\left(\mathrm{mm} \mathrm{d}^{-1}\right)$;

$\Delta=$ Gradient of saturated vapour pressure to air temperature $\left(\mathrm{Pa} \mathrm{K}^{-1}\right)$;

$\mathrm{R}_{\mathrm{n}}=\operatorname{Net}$ radiation $\left(\mathrm{J} \mathrm{d}^{-1}\right)$;

$\mathrm{G}=$ Soil heat flux $\left(\mathrm{J} \mathrm{d}^{-1}\right)$;

$\rho_{\mathrm{a}}=$ Air density $\left(\mathrm{kg} \mathrm{m}^{-3}\right)$;

$\mathrm{C}_{\mathrm{p}}=$ Specific heat of air at constant pressure $\left(\mathrm{J} \mathrm{kg}^{-1} \mathrm{~K}^{-1}\right)$;

$\mathrm{e}_{\mathrm{s}}$ and $\mathrm{e}_{\mathrm{a}}(\mathrm{Pa})=$ saturated vapour pressure and actual vapour pressure, respectively;

$\gamma\left(0.066 \mathrm{kPaK}^{-1}\right)=$ Psychometric constant; whilst $r_{s}$ and ra $\left(\mathrm{s} \mathrm{m}^{-1}\right)$ are the surface and aero dynamic resistance, respectively.

\section{Computation of reference evapotranspiration using FAO-56 Penman- Monteith equations}

TheFAO-56 PM equation being used for estimating the reference evapotranspiration is 
given as (Allen et al., 1998). The $\mathrm{ET}_{\mathrm{o}}$ was calculated with all necessary data according to FAO-PM, month to month for every year of the series, as well as using only the data from $\mathrm{T}_{\max }$ (maximum temperature) and $\mathrm{T}_{\min }$ (minimum temperature) of the air (hereafter Simplified FAO-PM); finally it was analyzed by regression. According to Pereira et al., (1997) and Allen et al., (1998), the FAO-PM equation can be calculated from

$$
E T_{0}=\frac{0.408 \Delta\left(R_{n}-G\right)+\gamma \frac{900}{T+273} u_{2}\left(e_{s}-e_{a}\right)}{\Delta+\gamma\left(1+0.34 u_{2}\right)}
$$

Where, $\mathrm{ET}_{0}$ is reference evapotranspiration $\left[\mathrm{mm}\right.$ day $\left.^{-1}\right], \mathrm{R}_{\mathrm{n}}$ is net radiation at the crop surface $\left[\mathrm{MJ} \mathrm{m} \mathrm{m}^{-2} \mathrm{day}^{-1}\right], \mathrm{G}$ is soil heat flux density $\left[\mathrm{MJ} \mathrm{m} \mathrm{m}^{-2}\right.$ day $^{-1}$ ], $\mathrm{T}_{\mathrm{a}}$ is mean daily air temperature at $2 \mathrm{~m}$ height $\left[{ }^{\circ} \mathrm{C}\right], \mathrm{u}_{2}$ is wind speed at $2 \mathrm{~m}$ height $\left[\mathrm{m} \mathrm{s}^{-1}\right], \mathrm{e}_{\mathrm{s}}$ is saturation vapour pressure $[\mathrm{kPa}], \mathrm{e}_{\mathrm{a}}$ is actual vapour pressure $[\mathrm{kPa}],\left(\mathrm{e}_{\mathrm{s}}-\mathrm{e}_{\mathrm{a}}\right)$ is saturation vapour pressure deficit $[\mathrm{kPa}], \Delta$ is slope vapour pressure curve $\left[\mathrm{kPa}{ }^{\circ} \mathrm{C}^{-1}\right]$, and $\gamma$ is Psychrometric constant $\left[\mathrm{kPa}^{\circ} \mathrm{C}^{-1}\right]$.

\section{Computation actual evapotranspiration} $\left(\mathbf{E T}_{\mathrm{a}}\right)$ using crop coefficient $\left(\mathbf{k}_{\mathrm{c}}\right)$ and reference evapotranspiration $\left(\mathrm{ET}_{0}\right)$ for Maize crop

The calculation of crop evapotranspiration $\left(E_{c}\right)$ under standard conditions, No limitations are placed on crop growth or evapotranspiration from soil water and salinity stress, crop density, pests and diseases, weed infestation or low fertility. $\mathrm{ET}_{\mathrm{c}}$ is determined by the crop coefficient approach whereby the effect of the various weather conditions are incorporated into $\mathrm{ET}_{\mathrm{o}}$ and the crop characteristics into the $\mathrm{K}_{\mathrm{c}}$ coefficient:

$$
\mathrm{ET}_{\mathrm{c}}=\mathrm{K}_{\mathrm{c}} \mathrm{ET}_{\mathrm{o} \ldots(3)}
$$

\section{Results and Discussion}

Reference evapotranspiration using the FAO-56 Penman-Monteith equation and Hargreaves Equation

Comparisons for FAO-56 penman-monteith equation and Hargreaves empirical equation were made between daily reference evapotranspiration values calculated by Hargreaves equations and daily values calculated using the FAO56-PM method. FAO56-PM was selected as a benchmark method for comparison, taking into account that is a globally accepted model, used under a variety of climatic regimes and reference conditions.

Although the coefficient of determination $\left(\mathrm{R}^{2}\right)$ has been widely used to evaluate the "goodness-of-fit" of evapotranspiration equations, it is oversensitive to extreme values (outliers) and insensitive to additive and proportional differences between estimated and measured values. Because of these limitations, $\mathrm{R}^{2}$ values when used alone can indicate that an equation is the best estimator of ETo when it is not. For that, additional statistical measures were included in the present effort.

Another way to evaluate the performance of the methods, in order to check whether one overestimates or underestimates ETo in comparison to FAO-56PM method, is to compare the monthly accumulated values of ETo, derived from the summed average daily values of both station per month (mm month ${ }^{-1}$ ) by estimating the difference and the standard deviation of their values (Tables 2 and 3).

By comparing the monthly accumulated values of ETo, it may be concluded that as far as seasonality is concerned, not only on a daily but on a monthly basis as well, all of the 
methods compared perform better during the winter season (October-February) with smaller deviations in absolute values of ETo and lower RMSE, but show proper performance during the summer season (March-September) with the opposite characteristics. In addition, both methods compared, during the summer season perform equally while during the winter season are showing deviations, in both stations (Tables 2 and 3; Fig. 2).

Table.1 Different metrological/hydrological/geo-hydrological data with respective sources

\begin{tabular}{|l|l|l|}
\hline Data & Description & \multicolumn{2}{|c|}{ Source of Data } \\
\hline $\begin{array}{l}\text { Hydrological } \\
\text { and } \\
\text { meteorological data }\end{array}$ & $\begin{array}{l}\text { Maximum and minimum daily } \\
\text { temperature, wind speed, daily } \\
\text { sunshine hour, relative humidity } \\
\text { Rainfall. }\end{array}$ & $\begin{array}{l}\text { Sevasadan } \\
\text { Godhra } \\
\text { Panam Dam Circle Office, } \\
\text { Godhra } \\
\text { MMRS, AAU, Godhra }\end{array}$ \\
\hline $\begin{array}{l}\text { Remote } \\
\text { Sensing data }\end{array}$ & MODIS Image, MOD16 Image & $\begin{array}{l}\text { Downloaded from United State } \\
\text { Geological Survey official } \\
\text { website, NASA, U.S.A. }\end{array}$ \\
\hline
\end{tabular}

Table.2 Summary of statistics of average monthly $\mathrm{ET}_{0}$ estimated method of FAO-56 PenmanMonteith equation and Hargreaves equation of Year 2006 to 2016

\begin{tabular}{|c|c|c|c|c|c|c|c|c|c|c|c|c|c|}
\hline \multirow{2}{*}{\begin{tabular}{|l} 
Sr. \\
No
\end{tabular}} & \multirow[t]{2}{*}{ Month } & \multicolumn{6}{|c|}{ Godhra } & \multicolumn{6}{|c|}{ Veganpur } \\
\hline & & $\begin{array}{c}\text { ETo } \\
\text { (FAO) }\end{array}$ & $\begin{array}{c}\text { SD } \\
\text { (FAO) }\end{array}$ & $\begin{array}{l}\text { ETo } \\
\text { (HR) }\end{array}$ & $\begin{array}{c}\text { SD } \\
\text { (HR) }\end{array}$ & COD & RMSE & $\begin{array}{c}\text { ETo } \\
\text { (FAO }\end{array}$ & $\begin{array}{c}\text { SD } \\
\text { (FAO) }\end{array}$ & $\begin{array}{r}\text { ETo } \\
\text { (HR) }\end{array}$ & $\begin{array}{c}\text { SD } \\
\text { (HR) }\end{array}$ & COD & RMSE \\
\hline 1 & January & 5.05 & 0.70 & 7.08 & 0.73 & 0.61 & 2.28 & 4.91 & 0.69 & 7.01 & 0.78 & 0.58 & 2.68 \\
\hline 2 & February & 6.49 & 0.94 & 8.56 & 1.14 & 0.67 & 2.87 & 6.34 & 0.9 & 8.76 & 1.22 & 0.66 & 3.49 \\
\hline 3 & March & 8.86 & 1.18 & 11.21 & 1.45 & 0.58 & 3.53 & 8.62 & 1.18 & 10.45 & 1.55 & 0.52 & 3.91 \\
\hline 4 & Apri & 10.52 & 1.07 & 10.18 & 1.17 & 0.66 & 4.26 & 10.28 & 1.08 & 9.49 & 1.35 & 0.56 & 4.81 \\
\hline 5 & May & 10.39 & 0.92 & 11.09 & 1.43 & 0.58 & 4.34 & 10.24 & 0.94 & 10.18 & 1.57 & 0.56 & 4.60 \\
\hline 6 & June & 7.95 & 1.74 & 10.78 & 2.54 & 0.60 & 5.15 & 7.78 & 1.69 & 9.69 & 2.50 & 0.49 & 5.36 \\
\hline 7 & July & 4.11 & 1.35 & 6.36 & 2.11 & 0.59 & 4.55 & 4.03 & 1.32 & 6.34 & 2.50 & 0.54 & 5.34 \\
\hline 8 & August & 3.48 & 1.03 & 6.44 & 1.86 & 0.54 & 4.49 & 3.41 & 1.02 & 6.00 & 1.68 & 0.54 & 5.06 \\
\hline 9 & September & 4.52 & 1.34 & 7.38 & 1.98 & 0.62 & 4.00 & 4.41 & 1.32 & 6.54 & 1.76 & 0.56 & 4.43 \\
\hline 10 & October & 7.32 & 1.09 & 9.17 & 0.95 & 0.56 & 2.72 & 6.92 & 1.07 & 8.78 & 1.08 & 0.48 & 3.26 \\
\hline 11 & November & 6.69 & 0.99 & 8.32 & 0.89 & 0.68 & 2.03 & 6.55 & 1.01 & 8.33 & 1.03 & 0.62 & 2.21 \\
\hline 12 & December & 5.49 & 0.59 & 7.45 & 0.64 & 0.58 & 2.29 & 5.38 & 0.59 & 7.52 & 0.78 & 0.58 & 2.47 \\
\hline
\end{tabular}


Table.3 Summary of statistics of average yearly ET $_{0}$ estimated method of FAO-56 PenmanMonteith equation and Hargreaves equation of Year 2006 to 2016

\begin{tabular}{|c|c|c|c|c|c|c|c|c|c|c|c|c|c|}
\hline Sr.No & Year & \multicolumn{9}{|c|}{ Godhra } & \multicolumn{6}{c|}{ Veganpur } \\
& & $\begin{array}{c}\text { ETo } \\
(\mathbf{F A O})\end{array}$ & $\begin{array}{c}\text { SD } \\
(\mathbf{F A O})\end{array}$ & $\begin{array}{c}\text { ETo } \\
(\mathbf{H R})\end{array}$ & $\begin{array}{c}\text { SD } \\
(\mathbf{H R})\end{array}$ & $\mathbf{C O D}$ & $\mathbf{R M S E}$ & $\begin{array}{c}\text { ETo } \\
\text { (FAO) }\end{array}$ & $\begin{array}{c}\text { SD } \\
(\mathbf{F A O})\end{array}$ & $\begin{array}{c}\text { ETo } \\
(\mathbf{H R})\end{array}$ & $\begin{array}{c}\text { SD } \\
(\mathbf{H R})\end{array}$ & $\mathbf{C O D}$ & $\mathbf{R M S E}$ \\
\hline $\mathbf{1}$ & 2006 & 5.81 & 1.01 & 8.58 & 1.19 & 0.76 & 2.98 & 5.64 & 0.95 & 7.61 & 1.26 & 0.82 & 3.25 \\
\hline $\mathbf{2}$ & 2007 & 6.99 & 1.02 & 8.53 & 1.36 & 0.44 & 2.01 & 9.99 & 1.01 & 8.9 & 1.46 & 0.34 & 2.64 \\
\hline $\mathbf{3}$ & 2008 & 6.9 & 0.92 & 8.72 & 1.42 & 0.56 & 2.51 & 6.78 & 0.91 & 8.74 & 1.48 & 0.55 & 2.47 \\
\hline $\mathbf{4}$ & 2009 & 7.25 & 1.18 & 10.19 & 1.43 & 0.5 & 5.06 & 7.14 & 1.17 & 9.94 & 1.57 & 0.36 & 4.39 \\
\hline $\mathbf{5}$ & 2010 & 5.6 & 0.99 & 8.69 & 1.34 & 0.59 & 3.2 & 5.48 & 0.99 & 7.53 & 1.47 & 0.48 & 4.41 \\
\hline $\mathbf{6}$ & 2011 & 6.42 & 1.01 & 9.9 & 1.49 & 0.55 & 3.6 & 6.25 & 1 & 9.66 & 1.53 & 0.52 & 3.58 \\
\hline $\mathbf{7}$ & 2012 & 7.61 & 0.94 & 10.54 & 1.48 & 0.62 & 4.1 & 7.43 & 0.97 & 9.53 & 1.38 & 0.61 & 3.92 \\
\hline $\mathbf{8}$ & 2013 & 6.98 & 1.15 & 8.61 & 1.42 & 0.67 & 2.33 & 6.82 & 1.09 & 8.62 & 1.57 & 0.67 & 2.56 \\
\hline $\mathbf{9}$ & 2014 & 7.28 & 1.31 & 8.57 & 1.36 & 0.77 & 2.35 & 7.1 & 1.3 & 10.23 & 1.48 & 0.73 & 5.15 \\
\hline $\mathbf{1 0}$ & 2015 & 5.53 & 1.31 & 8.12 & 1.54 & 0.7 & 5.52 & 5.53 & 1.29 & 7.95 & 1.54 & 0.64 & 5.68 \\
\hline $\mathbf{1 1}$ & 2016 & 5.56 & 1.03 & 7.82 & 1.4 & 0.7 & 5.12 & 5.56 & 1.01 & 7.49 & 1.53 & 0.69 & 5.09 \\
\hline $\mathbf{1 2}$ & 2006 & 5.81 & 1.01 & 8.58 & 1.19 & 0.76 & 2.98 & 5.64 & 0.95 & 7.61 & 1.26 & 0.82 & 3.25 \\
\hline
\end{tabular}

Table.4 Comparision of average actual evapotranspiration using the satellite based MODIS data and field data for maize crop in Panam command area of Year 2006 to 2016

\begin{tabular}{|c|c|c|c|c|c|}
\hline \multirow{2}{*}{ Sr.No } & \multirow{2}{*}{ Month } & \multicolumn{2}{|c|}{ Godhra $\mathbf{E T}_{\text {act }}(\mathbf{m m})$} & \multicolumn{2}{c|}{ Veganpur $\mathbf{E T}_{\text {act }}(\mathbf{m m})$} \\
\cline { 3 - 6 } & & MODIS 16 & Field Data & MODIS 16 & Field Data \\
\hline $\mathbf{1}$ & October & 5.403 & 4.915 & 5.789 & 5.367 \\
\hline $\mathbf{2}$ & November & 7.069 & 6.574 & 7.277 & 6.787 \\
\hline $\mathbf{3}$ & December & 5.464 & 5.682 & 5.449 & 5.453 \\
\hline $\mathbf{4}$ & January & 4.538 & 4.357 & 4.872 & 4.577 \\
\hline \multicolumn{2}{|c|}{ Indicies } & COD & 0.97 & COD & 0.99 \\
\hline \multirow{2}{*}{} & RMSE & 1.02 & RMSE & 1.53 \\
\hline
\end{tabular}


Table.5 Total $(\mathrm{mm})$ crop water requirement $\left(\mathrm{ET}_{\mathrm{c}}\right)$ of Maize crop of year 2006 to 2016

\begin{tabular}{|c|c|c|c|}
\hline Sr. & Month & \multicolumn{2}{|c|}{ ETc (mm) } \\
\hline $\mathbf{N o}$ & & Godhra & Veganpur \\
\hline $\mathbf{1}$ & $1^{\text {st }}$ Octo2006 $-15^{\text {th }}$ Jan 2007 & 433.23 & 423.88 \\
\hline $\mathbf{2}$ & $1^{\text {st }}$ Octo $2007-15^{\text {th }}$ Jan 2008 & 415.39 & 404.91 \\
\hline $\mathbf{3}$ & $1^{\text {st }}$ Octo $2008-15^{\text {th }}$ Jan 2009 & 433.16 & 426.86 \\
\hline $\mathbf{4}$ & $1^{\text {st }}$ Octo $2009-15^{\text {th }}$ Jan 2010 & 487.08 & 478.23 \\
\hline $\mathbf{5}$ & $1^{\text {st }}$ Octo $2010-15^{\text {th }}$ Jan 2011 & 312.49 & 307.33 \\
\hline $\mathbf{6}$ & $1^{\text {st }}$ Octo $2011-15^{\text {th }}$ Jan 2012 & 428.34 & 419.39 \\
\hline $\mathbf{7}$ & $1^{\text {st }}$ Octo $2012-15^{\text {th }}$ Jan 2013 & 438.34 & 430.40 \\
\hline $\mathbf{8}$ & $1^{\text {st } O c t o ~} 2013-15^{\text {th }}$ Jan 2014 & 428.34 & 419.39 \\
\hline $\mathbf{9}$ & $1^{\text {st }}$ Octo $2014-15^{\text {th }}$ Jan 2015 & 478.02 & 467.81 \\
\hline $\mathbf{1 0}$ & $1^{\text {st } O c t o ~ 2015 ~}-15^{\text {th }}$ Jan 2016 & 379.25 & 371.62 \\
\hline
\end{tabular}

Fig.1 Location map of study area

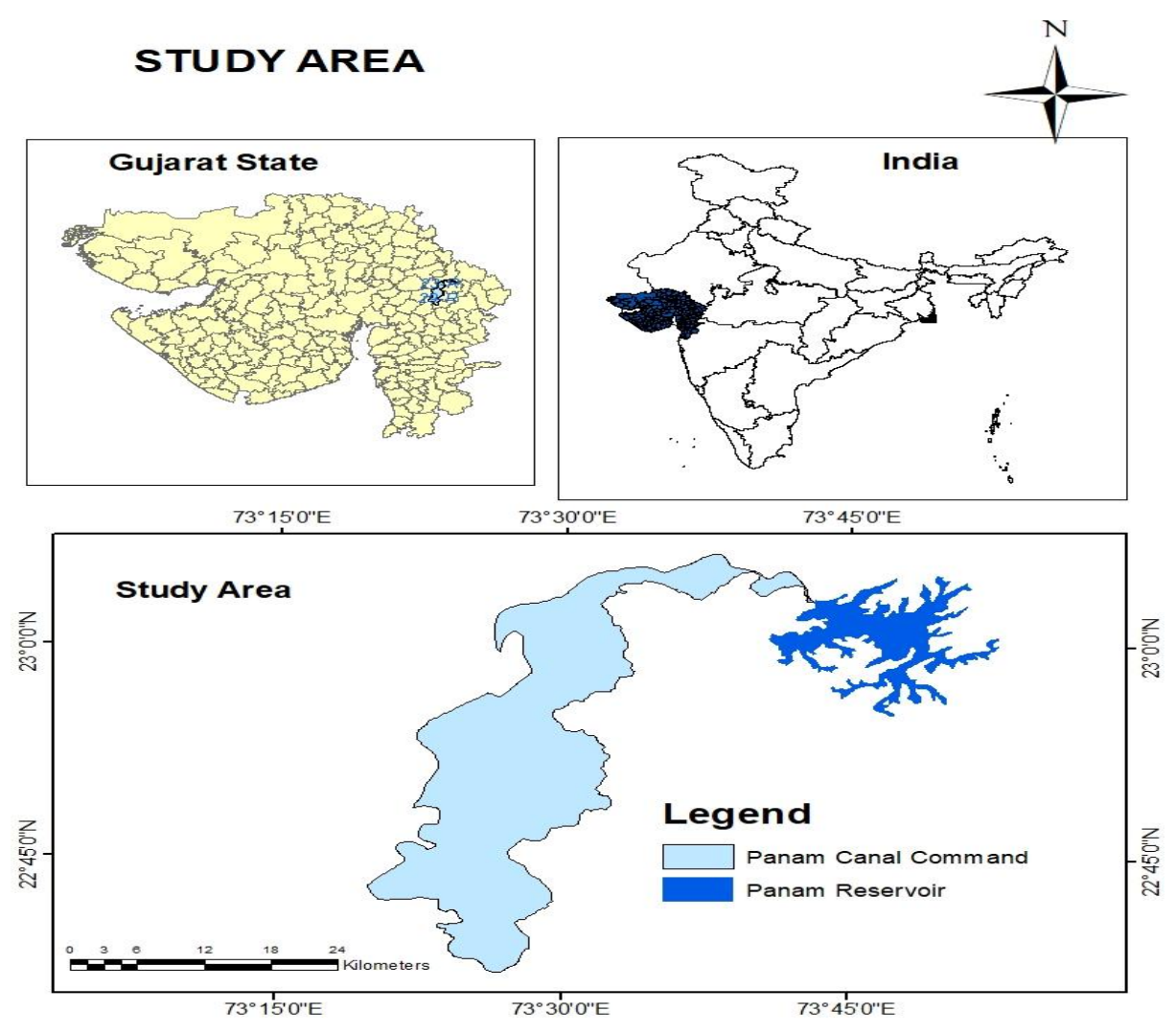


Fig.2 Flow chart of processing of MODIS image

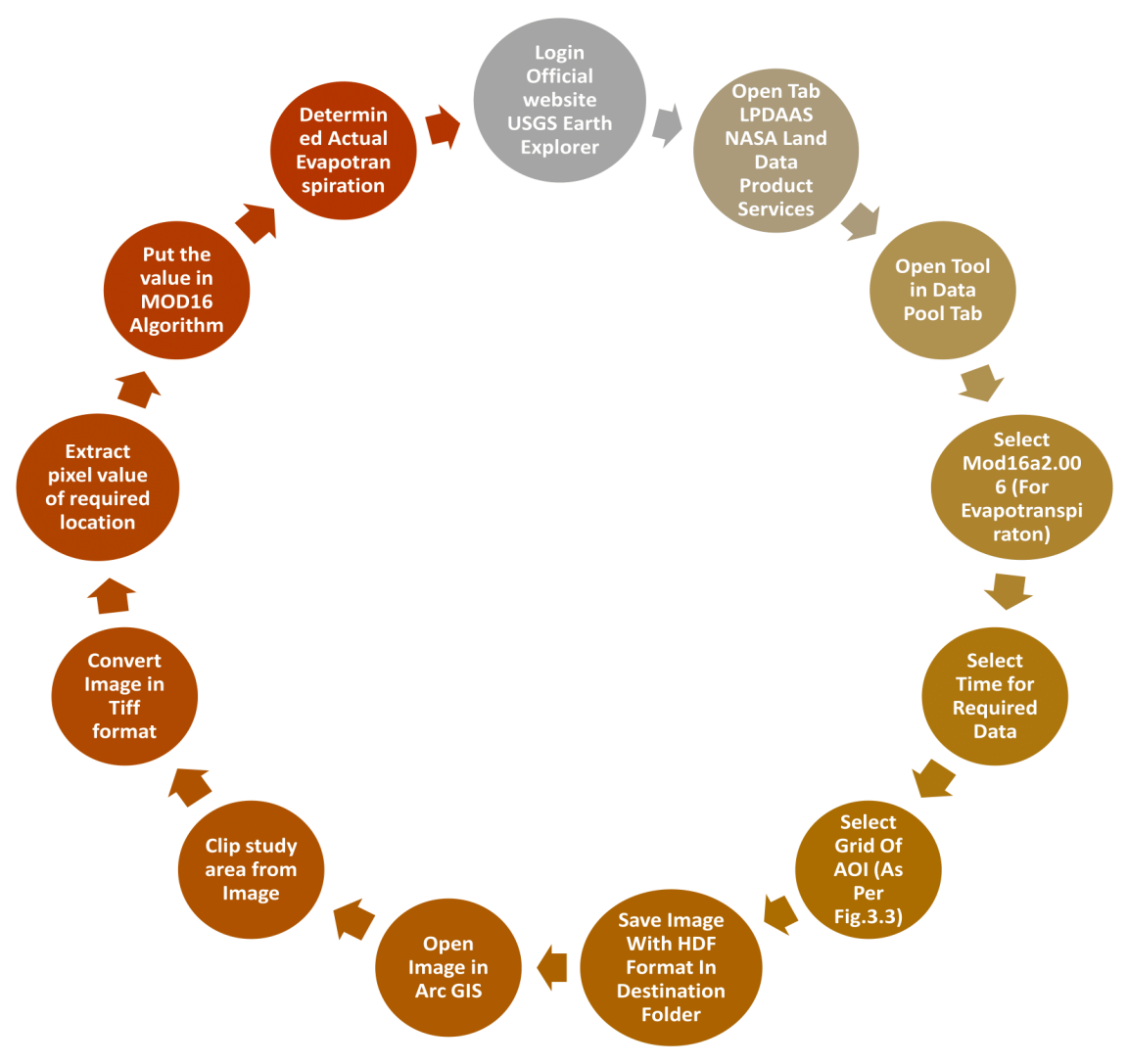

Average monthly standard deviation maximum value observed in June month was 1.74 in FAO- 56 Penman Monteith equation and minimum value observed in December month was 0.59 . The standard deviation for all year $\left(2006\right.$ - 2016) was nearly close, so $\mathrm{ET}_{\mathrm{o}}$ value for all study data nearly close to each other. Average monthly coefficient of determination maximum value observed in November month was 0.68 . These result indicate the these month data for good model regression and connection of data each other is strong. Coefficient of determination minimum value observed in October month was 0.48 , so these results indicate very week dependent variable.

Average root mean square error maximum value observed in June month was 5.36 and minimum was 2.03 in November Month. Average yearly standard deviation maximum value observed in year 2009 and 2013 was 1.57 in Hargreaves equation and minimum value observed in year 2008 was 0.91.The standard deviation for all year (2006 - 2016) was nearly close, so $\mathrm{ET}_{\mathrm{o}}$ value for all study data nearly close to each other. Average yearly coefficient of determination maximum value observed in year 2006 was 0.82 . These results indicate year data for good model regression and connection of data each other is strong. Coefficient of determination minimum value observed in year 2007 was 0.34 , so these results indicate very week dependent variable. Average root mean square error maximum value observed in year 2015 was 5.68 and minimum was 2.01 in year 2007. 
Comparison of average actual evapotranspiration using the satellite based MODIS data and field data for maize crop in Panam command area in winter season of year

Comparison of of actual evapotranspiration using the satellite based MODIS Data and field data for maize crop in Panam Command area in winter season for the years 2014 and 2015 is presented in Table 4. It can be observed from the tables that performance of MOD16 to calculate actual evapotranspiration is very close to that estimated using the field data.

Average crop water requirement of maize crop of year 2006 to 2016

Use of daily crop water requirement of maize of year 2006 to 2016, estimated seasonal crop evapotranspiration were given in Table by use of all stages water requirement. So highest maize crop water requirement was $487.08 \mathrm{~mm}$ in year 2009 at Godhra location and lowest maize crop water requirement was $307.33 \mathrm{~mm}$ in year 2010 at Veganpur same like Panam command area location.

Summary and conclusions are as follows:

The estimation of reference evapotranspiration is done using mainly with two method. First one is FAO-56 PM equations and second one is low requirement parameter, temperature based method Hargreaves equations. In the present study both the methods are applied for estimation of $\mathrm{ET}_{\mathrm{o}}$ in two sites i.e. Godhra and Veganpur located in Panam canal command and having metrological data of eleven year period (years 2006 to 2016). The estimation of actual evapotranspiration is estimated by using satellite based MOD16 data which is available in official website USGS earth explorer developed by NASA.
Based on the above study the following salient conclusions were drawn in tune to the objectives based on the estimated evapotranspiration method.

Mean yearly reference evapotranspiration estimated using Hargreaves equation of year 2006 to 2016 . $\mathrm{ET}_{\mathrm{o}}$ value for all year found near closely for the study of Godhra and Panam command area same like Veganpur location.

Highest $\mathrm{ET}_{\mathrm{o}}$ value were found $10.54 \mathrm{~mm}$ in year 2012 at Godhra location and lowest $\mathrm{ET}_{0}$ value like $7.49 \mathrm{~mm}$ for Veganpur location in year 2016. Maximum monthly mean $10.23 \mathrm{~mm}$ evapotranspiration was observed on April 2009 and minimum monthly mean 4.48 was observed on August 2006 month of the year.

Comparison of Monthly reference evapotranspiration estimated using FAO-56 Penman Monteith equation and Hargreaves equation of year 2006 to 2016. $\mathrm{ET}_{\mathrm{o}}$ value for all month found near closely for the study of Godhra and Panam command area same like Veganpur location.

The comparatively study revealed that in Godhra and veganpur regions. The $\mathrm{ET}_{\mathrm{o}}$ by both the methods of FAO - 56 Penman Monteith equation and Hargreaves equation showed nearly same result. Based on the result of both method, it was found that there was no significant difference in result, it shows that we can use Hargreaves equation instead of FAO - 56 Penman Monteith equation when unavailability of require meteorological data.

All in all, it can be emphasized that the use of the FAO56 -PM as a standard method remains the most appropriate method for estimating if the accuracy of the data collected is the main consideration. 
As the result for estimation of ET using the MOD16 remote sensing images are found very well, and considering their capability to produce the results for each $1 \mathrm{~km} \times 1 \mathrm{~km}$ grid, the MOD16 images are applied to assess the temporal and spatial variation of monthly ET over the Godhra and Panam command area.

Average monthly temporal and spatial variation over the Panam command is estimated using monthly MOD16 data for all the 11 year of 2006 to 2016 .

The scope of this study was to validate the 8day MOD16 ET product in an agricultural area, the Panam command area Godhra, India, for most of the growing season of 2006 - 2016.

The motivation behind this research was to attempt a validation of the MOD16 ET product on a regional scale against validated ET maps with the same spatial and temporal resolution.

Crop water requirement of maize crop in panam command area were found highest maize crop water requirement was $487.08 \mathrm{~mm}$ in year 2009 and lowest maize crop water requirement was $307.33 \mathrm{~mm}$ in year 2010 use of crop coefficient and reference evapotranspiration data.

The crop water requirement $\left(\mathrm{ET}_{\mathrm{c}}\right)$ was found to vary not only with the crops its stage and duration, but also with the season as well. The crops differed in water demand as the growing season changed. During initial stage of the crops, the $\mathrm{ET}_{\mathrm{c}}$ was less and increased during development stage, reached to its maximum values during mid season and reduced during crop maturation stages.

\section{References}

Allen, R. G., Pereira, L. S., Raes, D., and
Smith, $\quad$ M. 1998 Crop evapotranspiration-Guidelines for computing crop water requirementsFAO Irrigation and drainage paper 56. FAO, Rome, 300(9), D05109.

Allen, R. G., Tasumi, M., and Trezza, R. 2007. Satellite-based energy balance for mapping evapotranspiration with internalized calibration (METRIC)Model. Journal of irrigation and drainage engineering, 133(4), 380-394.

Autovino, D., Minacapilli, M., and Provenzano, G. 2016. Modelling bulk surface resistance by MODIS data and assessment of MOD16A2 evapotranspiration product in an irrigation district of Southern Italy. Agricultural Water Management, 167, 86-94.

Brutsaert, W. 2009. Hydrology: An Introduction, U.S.A: Cambridge University Press.

Cleugh, H. A., Leuning, R., Mu, Q., and Running, S. W. 2007. Regional evaporation estimates from flux tower and MODIS satellite data. Remote Sensing of Environment, 106(3), 285304.

Glenn, E. P., Nagler, P. L., and Huete, A. R. 2010. Vegetation index methods for estimating evapotranspiration by remote sensing. Surveys in Geophysics, 31(6), 531-555.

Hu, G., Jia, L., and Menenti, M. 2015. Comparison of MOD16 and LSA-SAF MSG evapotranspiration products over Europe for 2011. Remote Sensing of Environment, 156, 510-526.

Jang, K., Kang, S., Lim, Y. J., Jeong, S., Kim, J., Kimball, J. S., and Hong, S. Y. 2013. Monitoring daily evapotranspiration in Northeast Asia using MODIS and a regional Land Data Assimilation System. Journal of Geophysical Research: Atmospheres, 118(23).

Kim, H. W., Hwang, K., Mu, Q., Lee, S. O., 
and Choi, M. 2012. Validation of MODIS 16 global terrestrial evapotranspiration products in various climates and land cover types in Asia. KSCE Journal of Civil Engineering, 16(2), 229-238.

Monteith, J. L. (1965). Evaporation and environment, Symoposia of the Society for Experimental Biology, 19, 205-234.

Mu, Q., Heinsch, F. A., Zhao, M., and Running, S. W. 2007. Development of a global evapotranspiration algorithm based on MODIS and global meteorology data. Remote sensing of Environment, 111(4), 519-536.

$\mathrm{Mu}$, Q., Heinsch, F. A., Zhao, M., and Running, S. W. 2007. Development of a global evapotranspiration algorithm based on MODIS and global meteorology data. Remote sensing of Environment, 111(4), 519-536.

$\mathrm{Mu}$, Q., Zhao, M., and Running, S. W. 2011. Improvements to a MODIS global terrestrial evapotranspiration algorithm. Remote Sensing of Environment, 115(8), 1781-1800.

Ramoelo, A., Majozi, N., Mathieu, R., Jovanovic, N., Nickless, A., and Dzikiti,
S. 2014. Validation of global evapotranspiration product (MOD16) using flux tower data in the African savanna, South Africa. Remote Sensing, 6(8), 7406-7423.

Senay, G. B., Leake, S., Nagler, P. L., Artan, G., Dickinson, J., Cordova, J. T., and Glenn, E. P. 2011. Estimating basin scale evapotranspiration (ET) by water balance and remote sensing methods. Hydrological Processes, 25(26), 4037-4049.

Senay, G. B., Verdin, J. P., Lietzow, R., and Melesse, A. M. 2008. Global daily reference evapotranspiration modeling and evaluation. JAWRA Journal of the American Water Resources Association, 44(4), 969-979.

$\mathrm{Su}$, Z. 2002. The Surface Energy Balance System (SEBS) for estimation of turbulent heat fluxes. Hydrology and earth system sciences, 6(1), 85-100.

Pereira, M. A., FitzGerald, S. J., Gregg, E. W., Joswiak, M. L., Ryan, W. J., Suminski, R. R., and Zmuda, J. M. 1997. A collection of Physical Activity Questionnaires for health-related research.

\section{How to cite this article:}

Sanjaykumar H. Parmar and Mukesh K. Tiwari. 2020. Estimation of Reference and Crop Evapo-Transpiration in Panam Canal Command using Remote Sensing and GIS. Int.J.Curr.Microbiol.App.Sci. 9(08): 2141-2151. doi: https://doi.org/10.20546/ijcmas.2020.908.244 